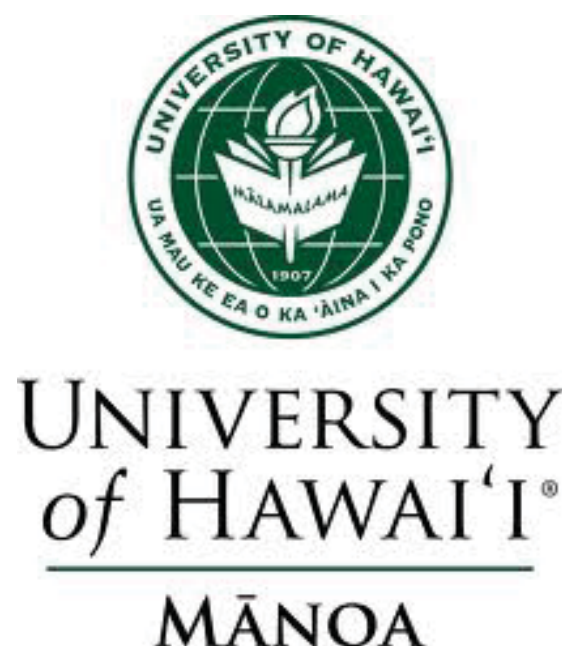

University of Hawai 'i at Mānoa Department of Economics Working Paper Series

Saunders Hall 542, 2424 Maile Way, Honolulu, HI 96822

Phone: (808) $956-8496$ www.economics.hawaii.edu

Working Paper No. 12-17

Disaster in Paradise: A Preliminary Investigation of the Socio-Economic Aftermaths of Two Coastal Disasters in Hawaii

\author{
By \\ John Lynham \\ Ilan Noy
}

August 2012 


\title{
Disaster in Paradise: A Preliminary Investigation of the Socio-Economic Aftermaths of Two Coastal Disasters in Hawaii
}

\author{
John Lynham and Ilan Noy
}

May, 2012

\begin{abstract}
In spite of a long history of coastal disasters worldwide and detailed studies of their short-term impacts, there is still little information about the longerterm economic and socio-economic consequences of these events. The long-term impacts of natural disasters are "hidden" since distinguishing them from other postdisaster developments is difficult. A decade after an event, how many of the observed changes in an economy can confidently be attributed to the event itself? Because the long-term effects of coastal disasters have rarely been studied, they remain unaccounted for in any pre- and post- disaster planning and policy decisions. We focus on the 1960 tsunami and the 1992 Hurricane Iniki on Hawaii and Kauai islands, respectively. The other Hawaiian Islands, which were not hit by the tsunami or hurricane, provide an ideal control group that potentially enables us to distinguish between long-term impacts and other post-disaster developments. We describe the regional macro-economy for the Hilo region in Hawaii and the immediate aftermath of the tsunami. We use Hurricane Iniki to demonstrate how to disentangle long-term consequences on Kauai and speculate what were the longterm impacts of 1960 Hilo tsunami.
\end{abstract}

JEL: Q54, R11

Keywords: coastal disasters, disaster impact, Hilo, tsunami, hurricane, Hawaii

Contact: John Lynham, Dept. of Economics, University of Hawai`i at Manoa, lynham@hawaii.edu, Ilan Noy, Dept. of Economics, University of Hawai i at Manoa, and Victoria Business School, Wellington, New Zealand, noy@hawaii.edu or ilan.noy@vuw.ac.nz. Acknowledgement: This work was funded by a grant from the National Oceanic and Atmospheric Administration, Project R/IR-22, which is sponsored by the University of Hawaii Sea Grant College Program, SOEST, under Institutional Grant No. NA09OAR4170060 from NOAA Office of Sea Grant, Department of Commerce. The views expressed herein are those of the authors and do not necessarily reflect the views of NOAA or any of its sub-agencies. 


\section{Introduction}

A large number of papers examine the short-term economic impact of specific disasters, and there is some comparative research on the short-term impact of disasters more generally (e.g., Belasen and Polachek, 2008, Noy, 2009 and Strobl, 2012). But research on the long-term (ten years or more) socio-economic impact of disasters is sparse; we know very little about long-term post-disaster trajectories or other economic and socio-economic dynamics following disaster events (Cavallo and Noy, 2011). Despite its importance, the reason why this issue has not been examined carefully is the difficulty involved in separating actual long-term effects caused by the disaster from those that would have still occurred even if the disaster had not.

In attempts to identify the economic impact of disasters on national economies, Skidmore and Toya (2002), in a widely mentioned paper, find a positive association between disaster frequency and long-run gross domestic product (GDP growth). They interpret this positive correlation as caused by a Schumpeterian creative destruction mechanism whereby the destruction of public and private infrastructure leads to a speeding-up of adoption of new technologies. In similar work, Ewing, Kruse and Thompson (2005 and 2009) find labor market improvements following a hurricane and a tornado, respectively. On the other hand, Noy and Nualsri (2007) and McDermott et al. (2011) use different empirical techniques and similar data sources and find, on average for developing countries, an adverse long-run effect on GDP (and little impact at the national level for developed/wealthy countries).

Another project, Cavallo, Galliani, et al. (2010), examines the impact on the national economy of specific catastrophic natural disasters and concludes that the evidence on a longterm adverse effect is driven by a few cases in which disasters were temporally associated, and possibly caused, a dramatic political regime change. The proto-type they identify is the large earthquake in Iran of 1978, which was then quickly followed by the Islamic Revolution of 1979 and the Iran-Iraq war that started in 1980. While the earthquake probably did not directly cause the collapse of the Iranian economy (a decrease of almost 50\% in per capita incomes in the decade that started in 1979), it most likely contributed to it. Most accounts describe the 
earthquake as a trigger for the Islamic revolution; both because of dissatisfaction with the existing regime's handling of the disaster, and as it enabled Islamic organizations to get valuable experience and 'feet on the ground' in much of the country when assisting in disaster recovery (e.g., Keddie, 2006).

The failure to establish robust patterns regarding post-disaster economic developments has led to some investigation of local impacts. In a related series of influential papers, several authors investigated the long-term impact of large-scale war-related destruction using geographically-detailed bombing data from World War II Japan (Davis and Weinstein, 2002 and 2008), the American-Vietnam War (Miguel and Roland, 2011), and Germany during World War II (Bosker et al., 2007). The first two papers failed to find any long term impact of the bombing campaigns on the distribution of economic activity; while the latter identifies evidence of longterm adverse impact of city destruction in Germany on city-size distribution. However, this 'impact-of-war' literature answers a different set of questions, since it is less clear that wars (and their associated destruction) are exogenous events. In fact, there is a large literature that argues otherwise, especially for civil wars. As endogenous events, attempts to disentangle the causes of war from its consequences are challenging.

To summarize, the literature on the long-term impact of economic shocks is inconclusive, but the weight of the evidence suggests no long-term impact of even catastrophic shocks at the national level. Several papers, however, do point to some potentially long-term impacts at the local/regional level, and this observation is our motivation to examine much more carefully the cases of two disasters in Hawaii: the 1960 tsunami in Hilo (generated by a catastrophic earthquake in Chile) and an unusually strong hurricane that destroyed much of the large infrastructure on the island of Kauai in 1992.

It is important to note at the outset that Hawaii's experience with disasters is not unique, as the economy of both of the affected islands is similar in important respects to other islands and coastal regions. Understanding what happened there may inform us on what to expect when destructive natural events hit vulnerable coastal areas elsewhere. This chapter is organized as follows. Section 2 provides some background information on the State of Hawaii. Section 3 describes the tsunami that struck Hilo, its short-term economic impacts and discusses 
what the long-term effects may have been. Section 4 builds on Section 3 by separating out the long-term economic impacts of Hurricane Iniki on the island on Kauai. Section 5 concludes with a general discussion and lessons for the future.

\section{The State of Hawaii}

Today, the State of Hawaii is home to nearly 1.3 million people. In 1960, the population of the Hawaiian Islands which comprise the State of Hawaii was about 632,000 while in 1992 it was around 1.1 million. ${ }^{1}$ The State includes four counties: the City and County of Honolulu, and Hawaii, Maui, and Kauai Counties. ${ }^{2}$ Honolulu and Hawaii counties are composed of the islands of Oahu and Hawaii, respectively; while Kauai County includes the island of Kauai and the tiny island of Niihau; and Maui County includes the islands of Maui, and the much more sparsely populated Lanai, and Molokai. About $80 \%$ of the population lives on the island of Oahu (City \& County of Honolulu), while the rest is divided about $8 \%$ each in Maui and Hawaii counties and $4 \%$ on Kauai. ${ }^{3}$

Similar to many other islands in the Pacific, tourism is the largest private sector industry today; but in 1960, agriculture and U.S. federal government spending (much of it militaryrelated) still dominated the economy; while by 1992 tourism was already the dominant sector that generated most income from outside the state. Although the counties differ in terms of population, they are nonetheless quite similar in terms of their economic activity. In 1960, the year of the Hilo tsunami, the population of each county was 500,409 for the City and County of Honolulu, 61,332 on Hawaii, 42,576 on Maui and 28,176 on Kauai.

In 1991, the year before Iniki hit Kauai, the resident population of Oahu was 850,500; Hawaii's population was 127,300 , Maui's was 105,600 , and Kauai County's was 53,400 . In the same year, real per capita income (measured in 2012 dollar units) was $\$ 39,600$ for the City and County of Honolulu, $\$ 27,600$ for Hawaii County, $\$ 32,160$ for Maui County, and $\$ 31,440$ for

\footnotetext{
${ }^{1}$ Source: State of Hawaii, Department of Business, Economic Development \& Tourism, http://hawaii.gov/dbedt (accessed 31/05/2012).

2 'Hawaii' is used both as the name for the whole Hawaiian archipelago and U.S. State, and for one of its constituent islands/counties.

${ }^{3}$ Data are obtained from the University of Hawaii Economic Research dataset, www.uhero.hawaii.edu (accessed $31 / 05 / 2012$ ).
} 
Kauai County. ${ }^{4}$ As for visitor arrivals, there were 4.8 million visitors to the City and County of Honolulu, 1.1 million to Hawaii County, 2.2 million to Maui County, and 1.2 million to Kauai County (UHERO, 2010).

Although both Kauai and Hawaii counties have a rich agricultural history, plantations throughout the islands have been in rapid decline since the 1970s. Today, agricultural activities account for only a small share of the state's economy. Currently, most of the federal government's military presence is on the island of Oahu (11\% of Oahu's total economic activity) and military spending is no longer a dominant aspect of the economy of either Kauai or Hawaii Island.

As the most populated island and the home of State government, Oahu has served as the "hub" of economic activity in the State. For example, in 2005, of the \$406 million in exports from Kauai, 60 percent were directed to Oahu. Only 8 percent were directed to Hawaii County and 9 percent to Maui County with the rest being exported out of the State. This is similar for the other neighbor islands, including the island of Hawaii ('Big Island') - where Oahu is by far the largest consumer of goods from all the other counties, and it has been this way since the early part of the $20^{\text {th }}$ century.

There are no other significant export sectors or domestic manufacturing. Since the counties (islands) are largely exporting comparable products (sugar and other agricultural products) and services (mostly tourism) they are subject to similar external political and economic shocks. Not only do the counties share similar economic structures (albeit different in size), but as they belong to the same political entity they are subject to the same institutional and legal frameworks. Most taxes are handled at the state level, and most expenditures are also decided at the state level; for example, uniquely in the United States, the public education system includes a single state-wide school district.

\section{The Hilo tsunami of $\mathbf{1 9 6 0}$}

\footnotetext{
${ }^{4}$ Unless stated otherwise, all dollar amounts are presented in terms of real 2012 dollars, adjusted using consumer inflation data.
} 
Tsunami is a Japanese term for large, sometimes destructive waves. Most ocean waves are caused by wind but tsunami are different. Tsunami are caused by sudden changes in the topography of the sea floor such as slippage along underwater faults, underwater avalanches, or underwater volcanic eruptions. The majority of tsunami are caused by fault movement. Underwater fault movement displaces the Earth's crust, generates earthquakes, and, if it ruptures the sea floor, produces a sudden change in water level at the ocean surface. If the sea floor is lifted or dropped vertically, this will generate a tsunami. Tsunami are not very high (typically only about 1.6 feet tall) but they move extremely fast. They typically go undetected in the open ocean until they reach shallow nearshore waters and begin to pile up.

On the $22^{\text {nd }}$ of May 1960, a tsunami was generated off the coast of Chile as a result of a major earthquake there. The tsunami struck the Hawaiian Islands 15 hours later, just after midnight on the $23^{\text {rd }}$ of May 1960; the tsunami was moving at a speed of approximately 445 miles per hour. In general, the wave action along Hawaiian shores was noticeable but not very significant or destructive (akin to a sped-up tidal change). However, in Hilo Bay on the island of Hawaii, the third wave of the tsunami converted into a bore. For comparison, on the island of Oahu, the average run-up recorded was 7 feet. In Hilo, run-ups as high as 35 feet were recorded near the waterfront area directly south of the breakwater (see Figure 1). This was surprising given that Hilo is sheltered from the direct approach of waves originating in Chile, and the harbor is protected by a seawall. 


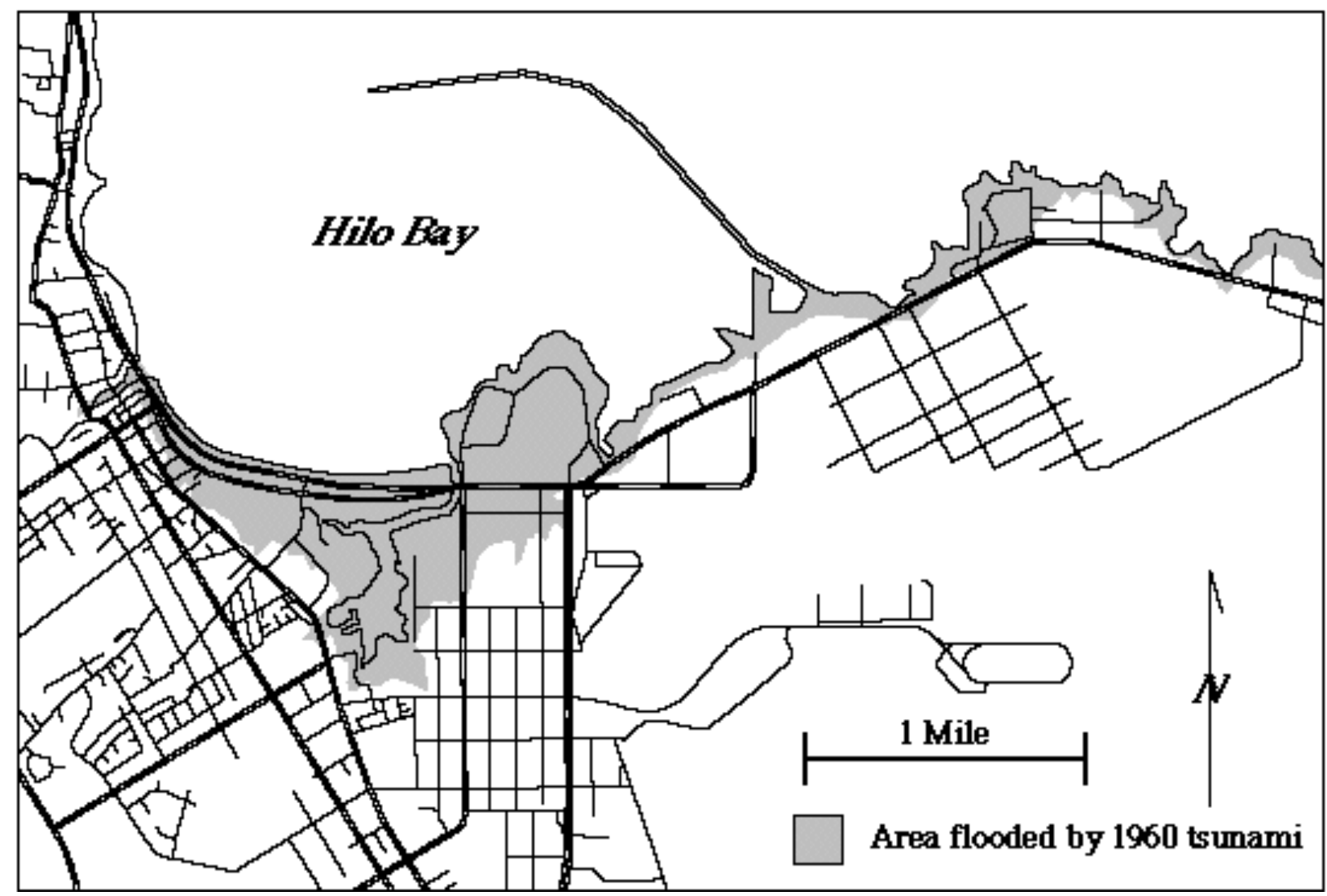

Figure 1. Map showing the area in the town of Hilo that was flooded in the 1960 tsunami. Image courtesy of the U.S. Geological Survey

The 1960 tsunami killed 61 people and injured 282 (Cox and Mink, 1963). All deaths and injuries occurred in the town of Hilo. This is despite warnings issued at 6:47pm on the $22^{\text {nd }}$ of May, at least 5 hours before the tsunami's arrival. Warnings were issued by radio, television, public address and in person. Only a third of the residents in the inundated areas chose to evacuate, as many did not feel there was much of a risk and the warnings were quite ambiguous (Lachman et al., 1960). This reaction is surprising since Hilo experienced an even deadlier tsunami in April, 1946 (159 people died) - this event led to the establishment of the Pacific Tsunami Warning Center that issued the 1960 alert and is still operating today.

In terms of physical damage, the brunt of the tsunami's force was focused on Hilo. Nearly 600 acres were inundated and in about half of this area, all buildings were destroyed completely (Eaton at al., 1961); the large number of wooden frame buildings meant that few 
structures remained standing (see Figure 2). In terms of the size of the destroyed area, this would be equivalent to 60 blocks in downtown Manhattan. The destruction was most severe along Kamehameha Avenue, the main thoroughfare of the city. On the rest of the island of Hawaii, only about a dozen other buildings were damaged. A number of automobiles, tractors and large machines were also destroyed in Hilo. Rocks weighing 22 tons were lifted from the harbor seawall and carried as far as 600 feet inland. There was hardly any damage to the other islands in Hawaii. Only a total of eight houses were destroyed on Maui, one on Lanai and none on Oahu, Molokai or Kauai. There was some flooding and damage caused to buildings' walls and their contents but nothing compared to the destruction in Hilo.

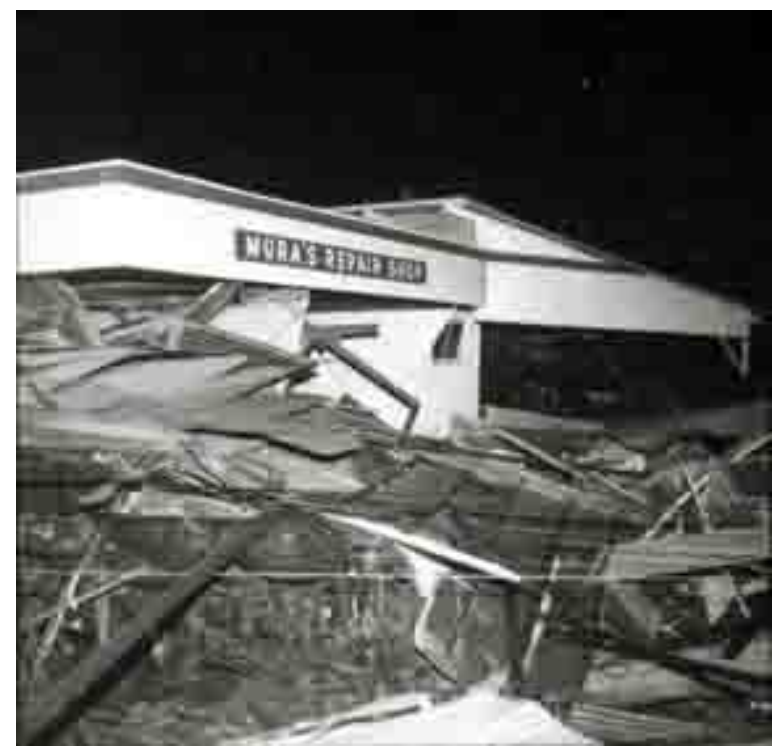

Figure 2. Hilo, May 1960; night photo of Mura's Repair shop, debris piled as high as the roof. Reproduced by permission of Pacific Tsunami Museum - Hawaii Tribune Herald Collection Economy of the Hilo region in 1960

In 1960, the city of Hilo was the center of economic and governmental activities on the island of Hawaii. At that time, $42 \%$ of the island's population lived in Hilo. The city and its vicinity accounted for $70 \%$ of gross retail sales and $83 \%$ of gross wholesale receipts. Almost all non-agricultural manufacturing activities were located in the city. The major sources of income 
on the island were agricultural (dominated by sugar but including other crops and animals) and some tourism.

\section{Table 1. Estimated damages in 2012 US\$ from the 1960 tsunami in Hilo.}

\begin{tabular}{l|l}
\hline Type of Damage or Loss & Amount \\
\hline \hline Commercial and industrial buildings & $55,296,000$ \\
\hline Stocks, fixtures and business losses & $49,920,000$ \\
\hline Public works and utilities & $29,184,000$ \\
\hline Residential Buildings & $17,664,000$ \\
\hline Emergency losses & $7,833,600$ \\
\hline Residential furnishings & $6,144,000$ \\
\hline Piers, wharves, contents & $2,304,000$ \\
\hline Miscellaneous personal property & 614,400 \\
\hline \hline Total & $\mathbf{\$ 1 6 8 , 9 6 0 , 0 0 0}$ \\
\hline
\end{tabular}

Source: US Corps of Army Engineers, Hilo Harbor, Hawaii, Report on Survey for Tidal Wave Protection and Navigation, Honolulu, 1960, p. C-32.

\section{Economic impact of the tsunami}

The estimated damage to residential, business and public properties was almost $\$ 169$ million (see Table 1 for a more detailed breakdown). ${ }^{5}$ Beyond loss of life and direct physical damage, a number of Hilo-based businesses suffered as a result of the tsunami. The State Department of Labor and Industrial Relations reported that 158 firms were directly affected by the tsunami. According to their records on the $15^{\text {th }}$ of June, 1960, of these 158 firms, 29 had resumed business at their prior site, 58 had relocated and 71 were still not operating. $A$ separate survey ${ }^{6}$ conducted on the $15^{\text {th }}$ of August, 1960 found that 172 firms had been damaged or destroyed, and of these: 44 reopened at their prior site, 63 relocated and 65 were

\footnotetext{
${ }^{5}$ The majority of the information in this section is sourced from Hung (1961).

${ }^{6}$ The survey was conducted independently by Nobuo Maruyama and reported in Hung (1961).
} 
still not operating. A follow-up survey conducted in July 1961 found that a total of 174 firms had been affected, and of these: 40 reopened at the same site, 90 had relocated and 44 were still not operating. See Table 3 for a summary.

\begin{tabular}{l|l|l|l|l|l}
\hline Date & Source & $\begin{array}{l}\text { Total } \\
\text { Businesses }\end{array}$ & $\begin{array}{l}\text { Resumed } \\
\text { Business }\end{array}$ & Relocated & $\begin{array}{l}\text { Not in } \\
\text { Operation }\end{array}$ \\
\hline 15-Jun-60 & $\begin{array}{l}\text { State Department of } \\
\text { Labor and Industrial } \\
\text { Relations }\end{array}$ & 158 & 29 & 58 & 71 \\
\hline 15-Aug-60 & $\begin{array}{l}\text { Agency (Mr. Nobuo } \\
\text { Maruyama) }\end{array}$ & 172 & 44 & 63 & 65 \\
\hline Jul-61 & $\begin{array}{l}\text { Hawaii Redevelopment } \\
\text { Agency (Mr. Nobuo } \\
\text { Maruyama) }\end{array}$ & 174 & 40 & 90 & 44 \\
\hline
\end{tabular}

Table 3. Businesses affected by the 1960 tsunami in Hilo.

Source: Hung (1961)

Unemployment on the island of Hawaii shot up in the month following the tsunami but appeared to recover quite quickly in the months following (Figure 3). The unemployment rate was 4.4\% (980 people unemployed) in May 1960 but jumped to 7.1\% (1,639 people) in July. It then declined gradually, probably due to employment created by recovery and relief efforts, with the unemployment rate in November 1960 falling back to similar levels to November/ December 1959. However, the unemployment rate began creeping back up in early 1961 and by June 1961, a year after the tsunami, the unemployment rate was 1.6 percentage points higher than what it had been in May 1960, just before the tsunami hit. This pattern of immediate losses in employment, followed by gains as a result of the cleaning and re-building effort, and an eventual disappearance of these gains, were observed in the aftermath of other 
cases of natural disasters as well. It also represents a significantly different trend from employment figures for the whole state (of which Hawaii island is only a small part). Employment in the whole state was growing continuously through this period (the 1960s). ${ }^{7}$

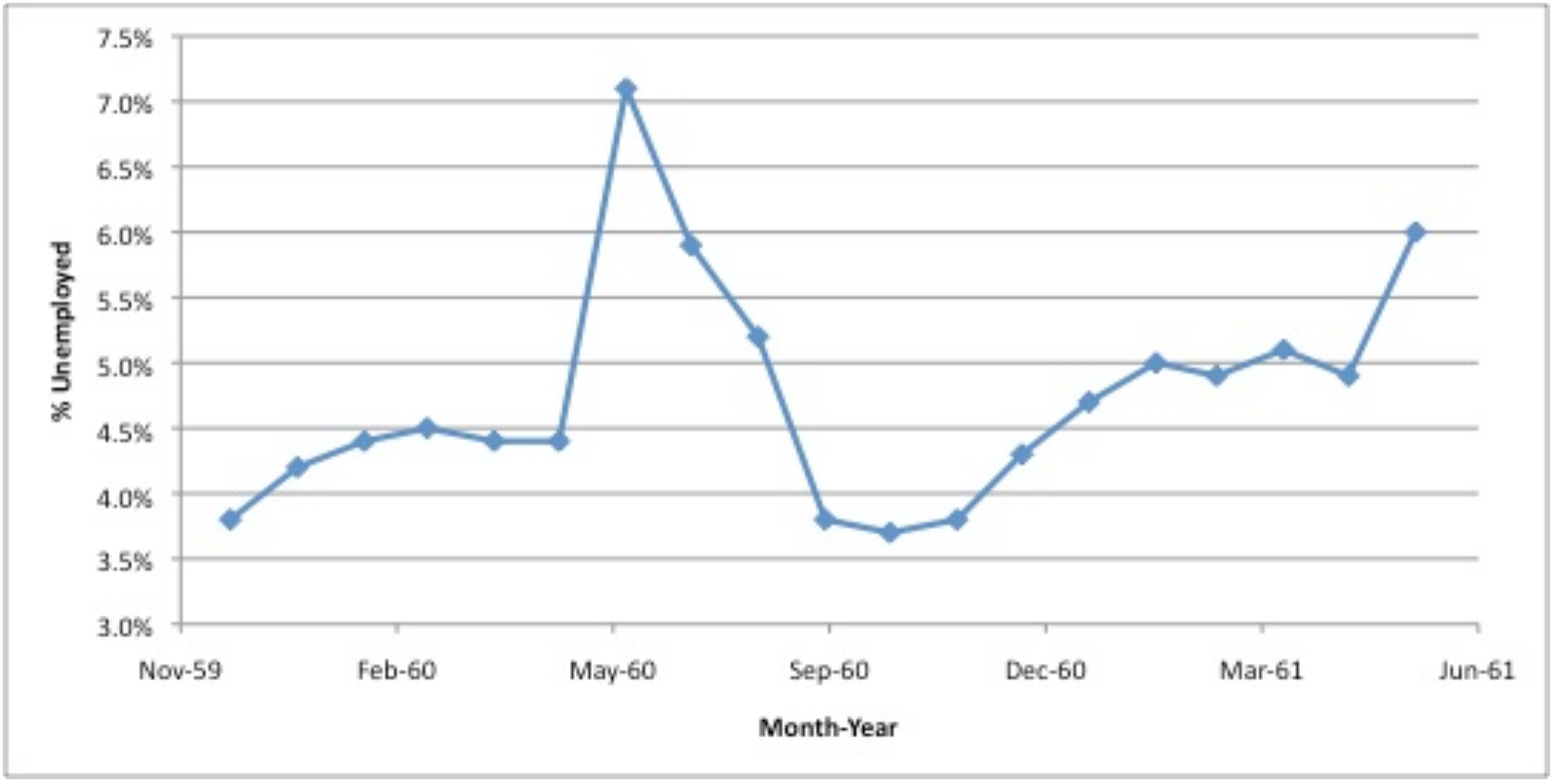

Figure 3. Unemployment rate before and after the May $23^{\text {rd }}, 1960$ tsunami.

Source: Department of Labor and Industrial Relations, Bureau of Employment Security

A survey conducted by Hung (1961) directly after the tsunami indicates the types of jobs that were lost as a direct result of the tsunami (see Table 4). The majority of job losses were in the retail sector (158 jobs), with the majority of these related to the sale of food and drink. The next two biggest sectors for job losses were services (45) and manufacturing (32). Not too surprising given the agricultural nature of the Hawaii Island economy at the time, the vast majority of the job losses in manufacturing were also food related.

\footnotetext{
${ }^{7}$ See State of Hawaii (1978), table \#4.
} 


\begin{tabular}{|c|c|c|}
\hline Business Type & & $\begin{array}{l}\text { Number } \\
\text { Unemployed }\end{array}$ \\
\hline \multirow{2}{*}{ Manufacturing } & Food & 27 \\
\hline & Wood, Printing, Fabricating, Apparel & 5 \\
\hline $\begin{array}{l}\text { Transportation, Communication, } \\
\text { Utilities, Warehousing }\end{array}$ & & 1 \\
\hline Wholesale & & 20 \\
\hline \multirow{5}{*}{ Retail } & Apparel & 15 \\
\hline & Food & 36 \\
\hline & Auto, Service & 23 \\
\hline & Eat, Drink & 63 \\
\hline & Miscellaneous & 21 \\
\hline \multirow{3}{*}{ Services } & Personal, Business & 25 \\
\hline & Hotels & 3 \\
\hline & Theaters, Recreation & 17 \\
\hline Fishery & & 21 \\
\hline Total & & 278 \\
\hline
\end{tabular}

Table 4. Unemployed as a result of the tsunami as of June 17, 1960. The numbers refer to the number of people employers reported as unemployed due to the tsunami.

Source: Hung (1961)

In terms of lost revenue, of the 158 firms that suffered major losses, 138 reported their gross receipts in 1959 and 1960. Gross receipts for all 138 firms in 1959 were $\$ 169,048,988$ and declined to $\$ 138,580,562$, representing a loss in revenue of over $\$ 30$ million (18\%). Similar to the rapid decline in unemployment following the initial surge, and despite these firms incurring heavy losses, other businesses in the Hilo area actually experienced an increase in sales in the months following the tsunami. For example, in a survey conducted by the Bank of Hawaii, from March to December of 1960, for those retailers that were still operating in December 1960, apparel sales increased $6 \%$ and general merchandise sales increased $7 \%$. Undamaged stores experienced a rise in business because of a lack of competition and there was a substantial 
increase in sales as a result of special sales of flood-damaged goods at reduced prices. Overall, the tax base on the island of Hawaii increased from the year 1959 to 1960.

The tsunami also affected where people chose to reside: a large part of the 1,155 families in the leveled Kaikoo region of Hilo moved to the two new areas allocated for that purpose; Lanakila Housing Project and the Waiakea area. Although the population of the city of Hilo decreased slightly from 25,966 in April 1960 to 25,775 in July 1960, it was back up to 26,871 by January $1^{\text {st }}$ of 1961 . Building activity, not too surprisingly, increased greatly on the island of Hawaii in 1960 and the first half of 1961. For example, the total number of building permits issued rose from 1,260 in 1959 to 1,406 in 1960. This was largely driven by the building boom in the city of Hilo to restore damaged and destroyed properties.

As more and more people chose to move inland following the tsunami, the value of land in the south Hilo district rose considerably. This is not reflected in the "assessed" value of the land but is reflected in the sale value of land. All 30 properties actually sold in the area shortly after the tsunami experienced an increase in price, despite no actual physical improvements to $93 \%$ of the properties. In fact, $57 \%$ of these properties experienced price increases of over $50 \%$ with some increasing in value by more than $200 \%$ !

Based on these raw numbers, it appears that the economy of the city of Hilo rebounded fairly quickly after the tsunami. However, it is difficult to disentangle genuine economic improvement from (i) broader macro-economic trends and (ii) the temporary boost in local economic activity generated by repair and rehabilitation projects. In order to distinguish the actual impact of the tsunami from the broader trends and to differentiate between the shortterm boost and longer-term impacts we need to be able to construct a counterfactual that would approximate for us the way Hilo would have developed had the tsunami of 1960 not happened; this procedure will necessitate more data collection from primary sources. As an example of how to construct such a counterfactual, we examine the second big natural disaster to hit Hawaii since Statehood; the 1992 hurricane that passed over the island of Kauai. 


\section{Hurricane Iniki of 1992}

Hurricane Iniki was the third hurricane to hit Kauai in the second half of the $20^{\text {th }}$ century, but the direct destruction wrought by Iniki was unprecedented. ${ }^{8}$ This category 4 hurricane landed on the south shore of Kauai in the afternoon hours of September 11, 1992. Four people were killed, 25,000 were affected, and there was 7.7 billion (2012 US\$) in destruction of infrastructure and property. ${ }^{9}$ According to the National Oceanic and Atmospheric Administration (NOAA, 1993), 14,350 homes were damaged or destroyed on Kauai; electric power and telephone service were lost throughout the island and only 20 percent of power had been restored four weeks later. Crop damage was extensive; tropical plants such as banana, sugarcane and papaya were destroyed, and fruit and nut trees were broken and uprooted.

At the time of the hurricane, Kauai was experiencing the effects of a prolonged and painful recession in Japan and, to a lesser extent, in the continental United States. The other Hawaiian Islands were also experiencing the impacts of these recessions. At that time, Japan was important for Hawaii's economy both because of the dominance of Japanese tourism in international arrivals, and the very large inflows of Japanese foreign investment, especially in real estate. To separate the effect of the hurricane from the effect of the Japanese recession and the aftermath of the Gulf War and the U.S. recession, a counterfactual scenario for Kauai without the hurricane needs to be established. The easiest way to do that is through a comparison with other regions that experienced the same external pressures, possessed the same structural vulnerabilities, but were spared any hurricane damage, namely the other Hawaiian Islands. ${ }^{10}$

The massive destruction of property and infrastructure resulted in a dramatic rise in unemployment. Unemployment was already inching up from a low of around 3 percent in 1990 to 6.8 percent just before the hurricane as the Japanese economy was suffering from the aftermath of its real estate and stock market bubbles. However, immediately after the hurricane, unemployment on Kauai shot up to 19.1 percent. It took Kauai's labor market seven

\footnotetext{
${ }^{8}$ The other two hurricanes were Dot in 1959 and Iwa in 1982.

${ }^{9}$ All data is from EM-DAT, The International Disaster Database, http://www.emdat.be/ (accessed 22/05/2011). EM-DAT cites 5 billion in 1992 US\$. We converted these to 2012 US\$ using CPI data.

${ }^{10}$ The counterfactual Kauai without the hurricane in the following figure is constructed as a weighted average of the other Hawaiian Islands. For details see Coffman and Noy (2012).
} 
years (until the second quarter of 1999) to recover to its previous pre-Iniki unemployment rate of 7 percent, while the number of private jobs available did not return to pre-Iniki levels until 2002, but even then, the recovery never brought Kauai back to its pre-Iniki trend. Evidence presented in Coffman and Noy (2012) suggests that Kauai experienced a permanent loss of about 3,400 private sector jobs (almost 15 percent of employment on the island) - see Figure 4 . This figure, as well as all the results cited here from Coffman and Noy (2012), was constructed using the synthetic control methodology described in Abadie et al. (2010). This same methodology is also used in Cavallo, Galiani et al. (2010). In essence, the methodology constructs a synthetic counter-factual data series from a weighted average of observations from other, unaffected, regions (in this case unaffected Hawaiian counties). The weights are estimated statistically to maximize fit using pre-disaster data from the affected (Kauai) and unaffected regions. A similar picture can be observed when the populations of Kauai and the counterfactual no-Iniki Kauai are compared.

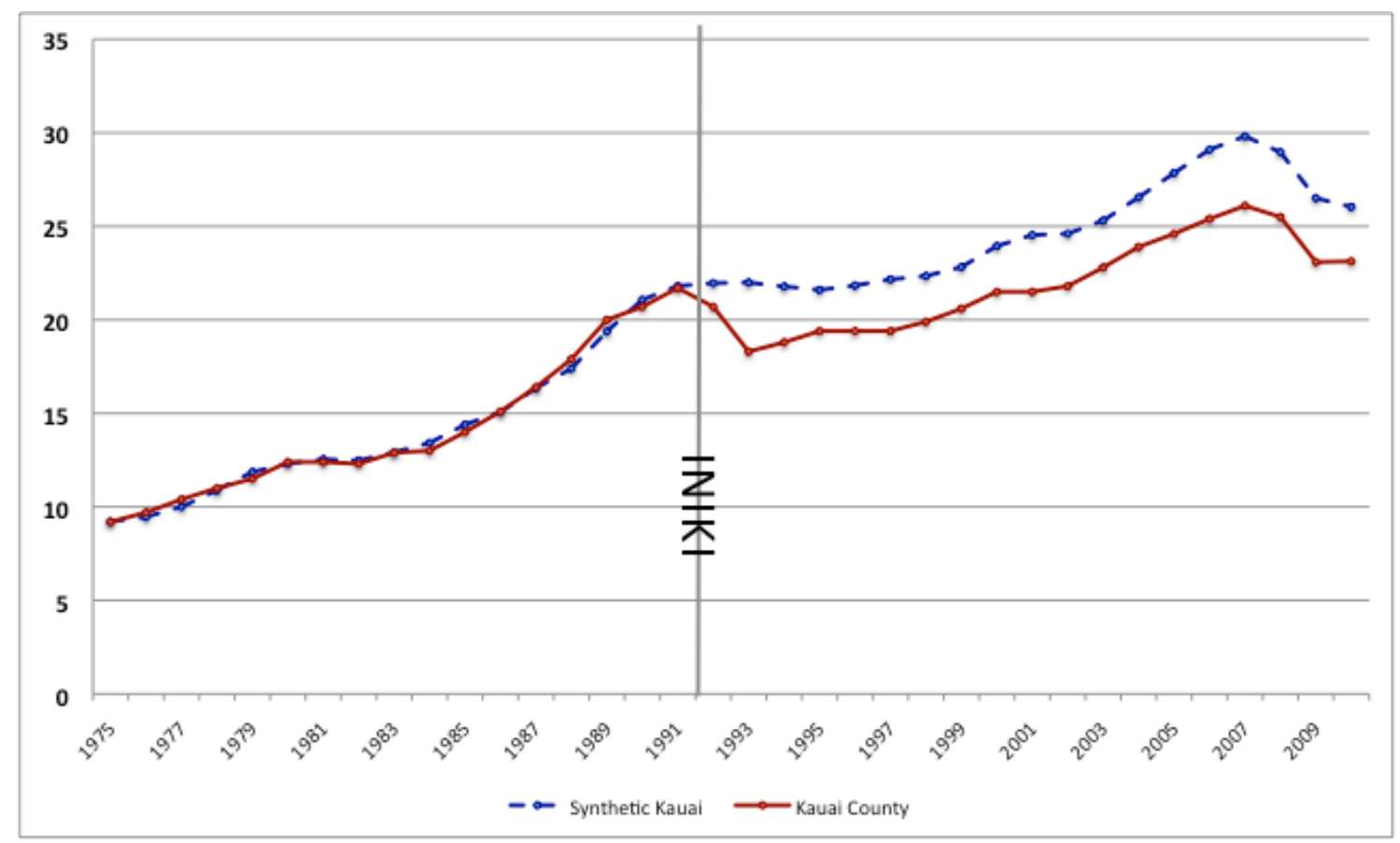

Figure 4: Total Private Sector Employment in Kauai and Synthetic Comparison (in thousands) Source: Coffman and Noy (2012). 
Kauai's population trajectory shifts in 1992. After many years of rapid growth Kauai's population grew much slower in the decade following the hurricane. It began to grow more rapidly again around 1999. However, Kauai never regained the population that left after the hurricane; Coffman and Noy (2012) estimate that Kauai's population would have been about 12 percent higher had Iniki never happened. This decrease in population was likely caused by the diminished employment opportunities following the hurricane. Over time, once residents realized that some jobs will not be coming back, some left as well. ${ }^{11}$ Eventually, per capita incomes returned to their pre-Iniki (and counterfactual) level, but the island's population has not. Kauai's experience with Iniki could have been much worse as it received substantial reconstruction funds from state and federal sources. This infusion of funds surely enabled a quicker recovery than it would otherwise have been the case. However, even so, by most measures the economy of Kauai only recovered after nearly a decade, and at least in the size of its population it has never fully recovered to this day. Of course, whether the absence of a complete recovery was undesirable for Kauai is not immediately clear; many on the island today praise its relative tranquility and its smaller population.

The case of Kauai demonstrates that the long-term impact of a large natural disaster, while hidden, may be identified given the appropriate comparisons and construction of counterfactuals. The case of the Hilo tsunami is also instructive. Prima facie evidence suggests that Hilo recovered very quickly, with employment and population in particular returning to their pre-tsunami trends within a couple of years. However, before 1960 Hilo was the center of economic activity, the center of gravity for the island of Hawaii; while some time later the main economic center of Hawaii Island shifted to the other (west) side of island - frequently referred to as Kailua-Kona. ${ }^{12}$ The reasons and timing of that shift are unclear; but it is plausible that the destruction to the coastal areas of Hilo in the 1960 tsunami contributed to the subsequent

\footnotetext{
${ }^{11}$ For example, the most famous Kauai hotel at the time, the Coco Palms - a popular destination for the Hollywood set, never reopened; at the time of writing the property is still shuttered and awaiting reconstruction a full 20 years after it was damaged.

${ }^{12}$ Named after the two largest towns in the area.
} 
tourism boom shifting its center of activities to the Kailua-Kona region; a shift that drove this movement of the economic center of gravity westward. ${ }^{13}$

\section{Other comparisons?}

Almost all the research on the impact of disasters on the economy of a specific region focuses on the short-term, but even this research makes interesting and suggestive observations that can assist us in identifying any general patterns regarding the long-term impacts of disasters. Vigdor (2008), for example, documents significant population declines in a carefully constructed investigation of Katrina's impact on New Orleans. As Vigdor acknowledges, it is impossible to separate these declines from a general declining trend in the area's population that long predates Katrina (and which Katrina clearly accelerated); at this point, it is difficult to predict whether the population of New Orleans will converge back to its pre-inundation trend, but the evidence seems to suggest that will not be the case, and that, not unlike Kauai's case, the population will never completely recover. Similar predictions have been made regarding the population of the North-East coast of Japan (the Tohoku region) that was most heavily impacted by the 2011 earthquake and tsunami. ${ }^{14}$

Another informative comparison is the earthquake experienced by the Japanese port city of Kobe in 1995. At the time, this was the biggest natural disaster to have hit Japan since the Great Kanto earthquake of 1923, and it was the costliest disaster of its kind in modern global experience. The perception at the time, and to this day, is that the Kobe region recovered quickly and efficiently and was back to 'normal' in three to four years (Horwich, 2000). Evidence presented by Chang (2009) and duPont and Noy (2012) both suggest that the recovery was not complete and that incomes in Kobe are today about $10-15 \%$ lower directly because of the earthquake.

\footnotetext{
${ }^{13}$ A similar shift of the economic center-of-gravity in California, from San Francisco to Los Angles, is sometimes attributed to the 1906 San Francisco earthquake that destroyed much of the city's downtown (e.g., Winchester, 2005).

${ }^{14}$ Clearly, the area around the damaged Fukushima-Daiichi nuclear power-plant may never recover completely, but in our context we are interested in the long-term consequences of the tsunami further north in the Tohoku region (see Noy, 2011).
} 
All of these cases-Hilo (1960), Iniki (1992), Kobe (1995) and New Orleans (2005)-are, of course, disasters in high-income countries. This may be important since there is much evidence to suggest that, in the short-term, recovery is faster the more funds for reconstruction are available. A massive post-disaster reconstruction program by the government, which was implemented in all these cases, may not be feasible and affordable for a lower income country to implement. In addition, accurate data to monitor economic recovery in lower income countries is rarely available (see the accompanying chapter on the 2004 tsunami in Thailand, which uses a qualitative research approach to chart the process of recovery).

Thus, the long-term economic or socio-economic impacts of catastrophic disasters on the impacted regions in middle or lower income countries are largely unknown. The massive earthquake that hit Port-au-Prince, Haiti, in January 2010 is an exceptional case - the most deadly disaster (relative to the size of the country's population) in modern history-but it still may be instructive. The earthquake killed about $2.5 \%$ of the country's population, and estimates suggest that damages were valued at more than a hundred percent of GDP (see Cavallo, Powell, et al., 2010). For comparison, the Kobe earthquake destroyed about 2-3\% of GDP. Clearly, the magnitude of this disaster will overwhelm any country, especially one as poor as Haiti.

Even though multilateral international organizations, and many governments, promised financial support for Haiti following the earthquake, previous examinations of similar cases suggest that there will be a significant shortfall, and that the amount of funds actually disbursed will not be sufficient to even cover the initial damage, let alone to enable the country any upgrade of its infrastructure (Becerra et al., 2010).

To summarize, we argue that the long-term economic impacts of disaster events are potentially very substantial, even though they are difficult to identify with the passage of time. Many predict that the future costs of natural disasters will increase substantially because of climate change, and especially to coastal areas which are vulnerable to tropical storms, flooding, and earthquake-generated tsunami. If this indeed will turn out to be what the future holds, we should be doubly concerned about the future long-term economic consequences of coastal disasters. 


\section{References}

Abadie, A., A. Diamond, and J. Hainmueller, 2010. Synthetic control methods for comparative case studies: Estimating the effect of California's tobacco control program. Journal of the American Statistical Association 105(490), 493-505.

Becerra, O., Cavallo, E.and Noy, I. 2010. In the aftermath of large natural disasters, what happens to foreign aid? University of Hawaii Working Paper 10-18.

Belasen, A. R., and Polachek, S. W. 2008 How hurricanes affect wages and employment in local labor markets. American Economic Review, 98(2), 49-53.

Bosker, M., Brakman, S., Garretsen, H. and Schramm, M., 2007. Looking for multiple equilibria when geography matters: German city growth and the WWII shock. Journal of Urban Economics 61, 152-169.

Cavallo, E., Galiani, S. Noy, I. and Pantano, J. 2010. Catastrophic natural disasters and economic growth. Inter-American Development Bank Research Working Paper \#183.

Cavallo, E., and Noy, I. 2011. The economics of natural disasters - a survey. International Review of Environmental and Resource Economics 5(1): 1-40.

Cavallo, E., Powell, A. and Becerra, O. 2010. Estimating the direct economic damage of the earthquake in Haiti. Economic Journal 120(546), F298-F312.

Chang, S. E., 2009. Urban disaster recovery: a measurement framework and its application to the 1995 Kobe earthquake. Disasters, 34(2), 303-327.

Coffman, M. and Noy, I. 2012. Hurricane Iniki: Measuring the long-term economic impact of a natural disaster using synthetic control. Environment and Development Economics 17(2), 187205.

Cox, D. C. and Mink J. F. 1963. The tsunami of 23 May 1960 in the Hawaiian Islands. Bulletin of the Seismological Society of America 53, 1191-1210. 
Davis, D., and Weinstein, D. 2002. Bones, bombs, and break points: The geography of economic activity. American Economic Review 92(5), 1269-1289.

Davis, D., Weinstein, D. 2008. A search for multiple equilibria in urban industrial structure. Journal of Regional Science, Vol. 48, No. 1, pp. 29-65.

duPont, W. and Noy, I. 2012. What happened to Kobe? A reassessment of the impact of the 1995 earthquake in Japan. University of Hawaii Working Paper 12-4.

Eaton, J. P., Richter, D. H. and Ault W. U. 1961. The tsunami of May 23, 1960, on the island of Hawaii. Bulletin of the Seismological Society of America 51, 135-157.

Ewing, B. T., J. B. Kruse, and M. Thompson. 2005. An empirical examination of the Corpus Christi unemployment rate and Hurricane Bret. Natural Hazards Review 6:191-6.

Ewing, B. T., J. B. Kruse, and M. Thompson. 2009. Twister! Employment responses to the May 3, 1999 Oklahoma City tornado. Applied Economics 41(6):691-702.

Horwich, G. 2000. Economic lessons of the Kobe earthquake. Economic Development and Cultural Change 48: 521-542.

Hung, F. C. 1961. Economic Impact of the 1960 Tsunami on South Hilo-Puna. Report prepared for the Planning and Traffic Commission, County of Hawaii

Keddie, N. 2006. Modern Iran: Roots and results of revolution, Yale University Press.

Lachman, R., Tatsuoka, M.and Bonk, W. 1960. Human behavior during the tsunami of May, 1960. Science 133: 1405-1409.

McDermott, T. K.J., Barry, F. and Tol, R. S.J. 2011. Disasters and development: Natural disasters, credit constraints and economic Growth. ESRI Working Paper \#411.

Miguel, E. and Roland, G. 2011. The long-run impact of bombing Vietnam. Journal of Development Economics, 96, 1-15. 
NOAA 1993. Hurricane Iniki - September 6-13, 1992. NOAA NWS Natural Disaster Survey Report.

Noy, I. 2009. The macroeconomic consequences of disasters. Journal of Development Economics 88(2): 221-231.

Noy, I. 2011. The economic aftermath of the recent earthquake in Sendai, Japan. European Business Review, May-June: 1-6.

Noy, I., and Nualsri, A. 2007. What do exogenous shocks tell us about growth theories? University of Hawaii Working paper 7-28.

Skidmore, M., and Toya, H. 2002. Do natural disasters promote long-run growth? Economic Inquiry 40(4): 664-687.

State of Hawaii, 1978. County Trends in Hawaii. Statistical Report \#128, Department of Planning and Economic Development.

Strobl, E. 2012. The economic growth impact of natural disasters in developing countries: Evidence from hurricane strikes in the Central American and Caribbean regions. Journal of Development Economics, 97(1), 131-140.

University of Hawaii Economic Research Organization, UHERO (2010), UHERO Economic Information Service Personal Income Summary, available at. www.uhero.hawaii.edu.

Vigdor, J. 2008. The economic aftermath of hurricane Katrina. Journal of Economic Perspectives 22(4): 135-154.

Winchester, S. 2005. A crack in the edge of the world: America and the great California earthquake of 1906. New York: HarperCollins. 